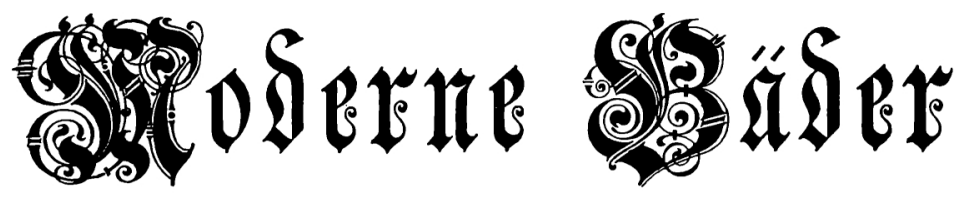

exläıtexf anก

\title{
Stuttgarter Schwimmbad
}

ynut

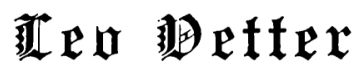

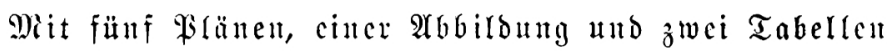

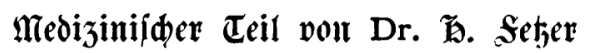

Errftes Taujend

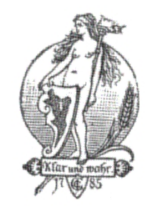

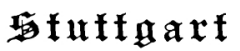

(S. $\mathfrak{s}$. Bsöjhen'ide Berlagshandrug 1894 
Das lleberfebungared t vorbehalten.

Irud von Cary Hembots in veilbrom. 